\title{
The impact of social transformation on the non-government welfare sector and the social work profession
}

\author{
Antoinette Lombard ${ }^{1}$ \\ ${ }^{1}$ University of Pretoria, South Africa \\ Correspondence to Antoinette Lombard, Department of Social Work and Criminology, \\ University of Pretoria, Lynnwood Road, Hillcrest, Pretoria 0002, South Africa \\ E-mail: antoinette.lombard@up.ac.za
}

Lombard $A$. The impact of social transformation on the non-government welfare sector and the social work profession Int J Soc Welfare 2008: 17: 124-131 ( 2008 The Author(s), Journal compilation (C) 2008 Blackwell Publishing Ltd and the International Journal of Social Welfare.

\begin{abstract}
This article examines changes to non-government social welfare, their impact on service delivery and on the social work profession. To redress the legacy of the past and the consequent inequalities in social welfare, in the first decade of democracy the government allocated the bulk of its welfare resources to transforming the social security system at the expense of social service delivery. As a result, South Africa has a costly social security budget with social services on the brink of collapse, leaving social workers and other social service professionals with low morale in the face of the huge challenge of providing welfare services with scarce resources, especially in the non-government sector. Nevertheless, social work remains an important role player in social development. From its marginalised position in the first decade of democracy, in the second decade it is repositioning itself as a recognised contributor to reconstruction and development in South Africa.
\end{abstract}

\section{Article Text}

The first democracy in South Africa was born in 1994. The Constitution of the Republic of South Africa (Act 108 of 1996) and the Reconstruction and Development Programme (Republic of South Africa, 1994) provided the legislative framework for the irreversible and rapid change to the policies governing South African society. Over the past decade the government has achieved a measure of success in transforming South Africa legislatively into a just, multi-racial democracy. In 2004, to mark the first ten years of democracy, all sectors of government were asked to assess their progress, especially in relation to policy development and implementation. Meanwhile, in the non-government sector, the government's neglect of social service delivery and its slow progress on policy implementation was giving cause for concern. Newspaper headlines read 'Social services in Gauteng [the richest of South Africa's nine provinces] are on the brink of collapsing. Our resources and personnel are so thinly spread that they struggle to render the most basic services' (Loffell, cited by Du Toit, 2006a: 11). In response to these negative press reports, the Ministry of Social Development confirmed that the intensive focus on social security in the first ten years of democracy had been to the detriment of other developmental social services (Department of Social Development, 2005a).

In his State of the Nation Address on 4 February 2006, President Mbeki reaffirmed the public perception that 'it would take (a) considerable time before we could say we have eradicated the legacy of the past' (Republic of South Africa, 2006a). In his speech he 
referred to the Markinor survey and its report that 65 per cent of South Africans believed that the country was going in the right direction, with 84 per cent believing that the country held promise for a happy future for all race groups and 71 per cent believing that the government was performing well. Based on these findings, President Mbeki claimed that 'What all these figures signify is that our people are firmly convinced that our country has entered its Age of Hope'. This envisioned 'Age of Hope' was extended to social welfare by the Minister of Finance, Trevor Manuel, in his Budget Speech on 15 February 2006 when he indicated that a core priority for 2006 was the strengthening of education, public health and social welfare services (Republic of South Africa, 2006b). From a provincial perspective, Ramokgopa (in Du Toit, 2006b: 11) confirmed that South African non-governmental organisations (NGOs) in the welfare sector could look forward to increased financing in the 2006/07 financial year. While the second decade of democracy might hold the promise of the intended 'Age of Hope', the previous decade can be depicted as an 'Age of Crisis' for social welfare service delivery and for the morale of social workers. In his State of the Nation address, President Mbeki premised this crisis on the legacy of the past (Republic of South Africa, 2006a). The footprints of apartheid were so deeply rooted in South African society in general, and in social welfare in particular, that it would take more than a decade of democracy to erase inequities and to build partnerships based on trust. The first decade had to deal not only with the historic impact of apartheid but also with the added consequences of ten years of neglect of social service delivery and its devastating impact on welfare NGOs generally and on the social work profession in particular.

It is time, however, to stop nursing past wounds and using them as an excuse to explain the lack of progress. Instead, we should look constructively towards the future. This is the spirit in which this article is offered, as an attempt to understand the current predicament of the non-government welfare sector and its impact on the social work profession and to reflect on the initiatives to put things right.

\section{Social service delivery in the non-government sector}

The enthusiasm that greeted the advent of democracy in South Africa has slowly eroded over the last ten years due to disappointment within the non-government sector on the way in which it has been treated by government. The Gauteng Social Services Funding Crisis Committee (2005) reported that in 1994 there was a great deal of optimism among progressive social service workers and community members for a new deal. The new social order and constitution founded on human rights assured the protection of vulnerable people and the access of all South Africans to the means for their development. The White Paper for Social Welfare (Republic of South Africa, Ministry for Welfare and Population Development, 1997) fostered hope that social welfare could move away from its historically marginalised status. Yet despite its good intentions and avowed commitment to developmental social welfare services, the Gauteng Social Services Funding Crisis Committee (2005) saw little change in the marginalised status of social welfare services in the first ten years of democracy. Nevertheless, the progress achieved should not be overlooked. In examining this progress in more detail, the following discussion focuses on a number of interacting factors that emerged in dealing with the legacy of the past and the crisis in social service delivery, namely, changes to the funding of social welfare services and their impact on the social work profession.

\section{Funding of non-government welfare services}

In South Africa the bulk of welfare funding has always gone to social security, and the democratic government followed suit, broadening the scope and efficiency of the social 
security system to address the high levels of poverty and deprivation in South Africa based on research showing the positive impact of social security on poverty alleviation

(Department of Social Development, 2005a). While not disputing the importance of social security, serious questions have been raised about the gross neglect of social welfare services (Gauteng Social Services Funding Crisis Committee, 2005) and their capacity to address the social conditions that give rise to poverty and underdevelopment (Department of Social Development, 2005a). Nevertheless, the 2004/05 budget allocated 91.6 per cent of the social welfare budget to social security and only 4.6 per cent to welfare services, with the latter being further divided between the government and non-government sectors (De Vries, 2004). In August 2005 more than 10 million of South Africa's estimated population of 47 million (Statistics South Africa, 2005) received social grants with 6.2 million children making up the majority of welfare recipients (Republic of South Africa, Ministry for Social Development, 2005). Social grants increased significantly from US $\$ 3.4$ billion in 2001 to US $\$ 8.5$ billion in 2005. The Department of Social Development (2005b) estimated that the social security budget would grow to over US $\$ 9.9$ billion by $2008 / 09$.

This expanding social security budget led to significant pressure on social services provided by both government and non-government sectors. The budget for social services has not kept pace with the demand for services (Department of Social Development, 2005a). Even with the promise in 2006 of R423 million (US\$60 million) for the Gauteng provincial government, an increase of R160 million (US\$23 million), there remains a R100 million (US\$14 million) shortfall in the resources required to address the most basic needs of the increasing number of vulnerable children and elderly people (Du Toit, 2006c). Du Toit (2006c) cites Barberton, an independent economist, who estimated that a budget of $\$ 85$ million would be required to run an efficient welfare system. It is thus highly likely that the neglect of social service delivery will continue in the second decade of democracy. The Department of Social Development (2005c: 11-12) reported on the far-reaching impact of the neglect of social services as follows:

- Inadequate numbers of social service practitioners to deal with high caseloads and deepening poverty.

- Large numbers of children awaiting trial in prison due to a shortage of probation workers and a lack of infrastructure, such as places of safety and secure community care facilities.

- Very poorly developed prevention and early intervention services.

- An increase in social pathology and social problems, such as substance abuse, street children, child sexual exploitation and HIV and AIDS.

- Inability of service providers in the non-government sector to render services because of inadequate remuneration for these services and difficulties with fundraising, resulting in services being in a state of collapse.

Non-government, not-for-profit organisations provide the bulk of services to address social pathology and social problems (Gauteng Social Services Funding Crisis Committee, 2005). As a result of the funding crisis, many essential non-government welfare organisations are closing down. For example, in February 2005, Victim Support SA, a section 21 company which coordinated community-based victim support projects at 300 police stations around the country, closed its doors (Gauteng Social Services Funding Crisis Committee, 2005). The government's failure to support the non-government welfare service delivery sector also raises questions about its commitment to developmental social welfare. Social grants, which have been extensively marketed by the State President, politicians and government officials during voting campaigns and imbizos (community forums), have elicited strong public support and a public view that social welfare is remedial and maintenance oriented. In the face of the expanding nature of social security at the cost of developmental social services, changing the name of the national Department of Social Welfare to the Department of Social Development led to growing concerns that 'social development' was being equated with the 'hand-out' charity model of social welfare. The First Lady, Zanele Mbeki, criticised the government's policies on fighting poverty, stating that more welfare would not buy the poor out of their misery and warning that '[w]e should not make a welfare state and call it a developmental state' (in Boyle, 2005: 1). In his Budget Speech on 18 February 2004, the 
Minister of Finance declared that in the long term the government would not be able to sustain the current high level of expenditure on social grants and that the only way to counteract citizens' increasing dependence was to seek a better balance between growth in welfare spending and investment in education and infrastructure development (Republic of South Africa, Budget Speech, 2004). To address problems in the public administration of social grants, especially at provincial level, the Minister introduced a national South African Social Security Agency (SASSA), which was due to be fully operational by April 2006 (Department of Social Development, 2005b). As a result, both the national and provincial departments of social development have been engaged in a restructuring process to reposition themselves mainly as providers of social development services. Their brief is to develop, implement, monitor and evaluate the impact of policies, norms and standards for quality service delivery (Department of Social Development, 2005c).

The has led to the development of the Service Delivery Model for Developmental Social Services (Department of Social Development, 2005c), which is the government's direct response to deal with the neglect of social welfare service delivery (Department of Social Development, 2005b). However, this model is not new and merely constitutes a return to the goal of the White Paper for Social Welfare (Republic of South Africa, Ministry for Welfare and Population Development, 1997) to provide an 'integrated developmental welfare system'. Thus, the service delivery model provides yet another national comprehensive framework that sets out the nature, scope and level of social services. Finally, eight years after its emergence, the government has developed a strategy to implement developmental social welfare and a process to conduct a realistic appraisal of the cost of such services. It re-affirmed its commitment to provide adequate resources for its effective implementation with clear benchmarks or norms and standards for service delivery. Although this model is a step in the right direction, its success 'depends largely on continuous review, customisation to suit settings of implementation, and identification with and total ownership by the sector' (Department of Social Development, 2005c: 10). The true test lies in its potential to address the backlog in social services; the discrepancies in and inadequate budgets for the funding of social welfare services; the lack of a costing model based on specific norms and standards for the financing of social welfare services; and the impact of the transformation agenda on the financing of social welfare service delivery.

The lack of transparent or standardised criteria for the financing of social services (National Coalition of Social Services, 2004) has led to major discrepancies in the allocation of funds to non-government organisations working within the same area or field of welfare across the nine provinces in South Africa. The politics of the day substantially influences funding policies, as was evident in race-based apartheid funding, which has made its way into the current government's developmental approach to welfare (Smit, 2005). Historically, the financing of non-government welfare services was racially determined and the bulk of the money went to funding salaries for social workers who were the key providers of social welfare services in the non-government sector. The capacity of this sector, and that of the social work profession, was built on government subsidies to private welfare NGOs. Smit's (2005) research on funding strategies for social welfare services revealed that nothing had changed despite the Financing Policy for Developmental Social Welfare Services (Republic of South Africa, Department of Welfare 1999), which was intended to transform social welfare service delivery to a developmental approach. This policy, however, did not provide a costing model for social service delivery and it was not fully implemented in all the provinces. The gap in funding social welfare services therefore prevailed and funding continued to be based on social work salaries. Instead, what was needed was a funding policy that would provide for the financing of the services provided by the non-government sector and realistic and appropriate budget allocations for these. This would do much to redress the disparities in the provision of welfare services within and across the provinces. Thus, the Policy on Financial Awards to Service Providers (Department of Social Development, 2004b) looked beyond social work posts to resourcing services in terms of transformation and performance criteria (Smit, 2005). However, it was very vague and was followed by procedural Guidelines for the Implementation of the Policy on Financial Awards to Service Providers (Department of Social Development, 2005d). Their aim was to give 'broad direction on the implementation of the policy on Financial Awards' (Department of Social Development, 2005d). Instead, what it did was to provide 'vague direction' on 
financial criteria, which still left NGOs in the dark on norms and service standards and key performance indicators. This is evident in the following statement from the procedural guidelines:

The financial criteria will be based on formulae ... approved by the Head of the department on recommendation of the Chief Financial Officer ... The formulae for funding will be informed by the costing models that the department will determine from time to time but allocation will also be made subject to the availability of funds. The proposed costing models are defined as tools to be used in the financing of developmental social programmes. They will ensure that resources are directed to the most needy and government provides for primary services that are affordable (Department of Social Development, 2005d: 18).

While the guidelines allowed provinces to develop more specific procedures to address provincial peculiarities (Department of Social Development, 2005d), their lack of clear funding criteria held little promise of eliminating discrepancies. In short, despite repeated attempts to introduce a fully functioning programme-based funding policy, welfare organisations continued to receive subsidies based on the former social work salary-based policy (Smit, 2005). The National Coalition of Social Services (NACOSS) (2005) saw this as totally inadequate for other personnel and argued that operational costs must be taken into consideration in the costing model for the financing of welfare programmes. NACOSS based its proposal on the higher salary rates and levels of remuneration paid in the public sector. Thus, Smit (2005: 352) concluded that 'despite the enterprising initiative of some seven decades ago when social workers were first subsidised, the countless funding policies issued since then and the last 20 years of programme funding talk, ominously little progress has been made'.

Government plays a major role in organising and resourcing social welfare services either by supplying services itself or by outsourcing services to NGO providers. Hence, clear guidelines as to how such services will be funded are vital. As a contractor for services, the Department purchases services in three ways: (i) through subsidising programmes that meet its basic requirements for funding; and (ii) through open or (iii) closed tender (Department of Social Development, 2005d). One of the requirements for government funding is the extent to which welfare NGOs are meeting the transformation objectives of the Department of Social Development. According to the Director of Partnerships and Welfare Financing of the Gauteng Department of Social Development, NGOs are obliged to present a transformation plan for approval by government (Du Toit, 2006c: 4). However, while the Social Development Service Delivery Model (Department of Social Development, 2005c) lists the roles and responsibilities of service providers, it is not very specific with regard to the transformation criteria and provides little guidance on what this means in practice other than the stipulation that management boards and personnel reflect the racial composition of the South African population and that there is no discrimination in terms of race, culture and religion (Du Toit, 2006c). Better established NGOs are expected to share their already inadequate resources and knowledge with smaller, community-based organisations and to have a strategy in place as to how they are going to decrease their dependence on the state. These so-called clear guidelines have led to a great deal of confusion in the NGO sector. Thus, said Jackie Loffell (cited by Du Toit, 2006a: 11), the director of a major NGO, that different interpretations of transformation requirements are a huge stumbling block. While acknowledging that the new government had to reform the welfare sector into one that oversees all those in need, 'it made the mistake to think that the so called "white" NPOs had all the resources whilst they in fact merely had none' (Loffell, cited by Du Toit, 2006a: 11). Having 'more' due to access to funds from the former government should therefore not be confused with having enough.

Clearly, more open discussion is needed to reach consensus on the respective roles of the government and non-government sector in policy development and implementation, in service provision and on levels of funding for services in the non-government sector. Over the years non-government networks, such as NACOSS, have participated fully with government in policy initiatives, such as the design of the White Paper for Social Welfare, 
and more recently on a costing model for social services. Effective partnerships between government and NGOs are crucial. While the government facilitates the development of funding policies and guidelines, NGOs should work on their strategies towards financial independence. Provincial government funding currently accounts for between 30 and 50 per cent of income in the non-government sector. Income from corporate social investment averages 22 per cent and in rare cases reaches 43 per cent (Gauteng Social Services Funding Crisis Committee, 2005). Given the funding crisis of social welfare services in South Africa, welfare organisations will increasingly have to become less dependent on state financing. However, very few organisations are within reach of this goal, with the Association for People with Physical Disability: Gauteng North being a rare exception. The reality is that as much as there is a dire need for clearer guidelines for government funding of social welfare services, there is, simultaneously, a great need for NGOs to build their capacity and funding strategies. Smit's (2005: 355$)$ study of 376 NGOs revealed that 72 per cent of organisations did not have a marketing plan, only 36 per cent had a database of funding sources, and only 8 per cent operated a registered 'for-profit' business organisation to generate their own source of income. Alarmingly, 68 per cent indicated that direct service professionals (social workers) were sometimes expected to spend time on fundraising, thus preventing them from providing needed professional services. Clearly, both government and NGOs have homework to do with regard to funding policies and strategies to get social welfare services back on track. Given that social workers' salaries and their continued role in service provision are central to the funding debate, we will now examine this.

\section{The pivotal role of social workers in the NGO sector}

Social workers have always played a major role in welfare service delivery in South Africa, both in the government and non-government sectors, and saw the new democracy as an opportunity to contribute to the achievement of social justice for all South Africans. Their acceptance of the White Paper for Social Welfare (Republic of South Africa, Ministry for Welfare and Population Development, 1997) was testimony to the fact that the profession was ready to embark on a developmental approach to social welfare that would bring Batho Pele (People First) development to the nation. However, despite the paradigm shift towards developmental social work, the first decade of democracy has been overshadowed by doubts about social work's commitment to the new policy of social development and questions relating to the profession's ability to contribute to, and deliver upon, social development goals (McKendrick, 2001). Thus, the Department of Social Development (2004a: 43) noted that 'The status of the social work profession has been undermined and (as a result we have)... witnessed an unprecedented undermining of confidence and belief in the ability of the Social Work profession'. In fact, as contributors to social development and nation-building, social workers were increasingly sidelined, and their profession marginalised, leaving them feeling quite demoralised (Gray, 2000). In response, McKendrick (2001: 105) voiced his opinion that social workers were 'undergoing a crisis of confidence in themselves, their profession, and their ability to make an important contribution to [ . . .] social development'. This crisis escalated to national proportions threatening the progress of the welfare sector with headlines in national publications such as 'Crisis in welfare affects rich and poor' (Koegelenberg, 2003) and 'Social workers face war of attrition' (McKay, 2003: 15). The urgency of the matter was finally addressed when the national Minister of Social Development, Zola Skweyiya, appealed for greater recognition of 'the work of social workers' (South African Press Association, 5 March 2003). Several initiatives then followed that recognised social work as an important resource and a 'scarce skill'. These included an investigation into social workers' salaries and service conditions and a draft recruitment and retention strategy to address (i) the exodus of social workers from the country and the profession, which was a direct result of the neglect of the social services sector where most social workers were employed, and (ii) the need to attract social work students given the negative public profile and low morale of the profession generally. While social work has always been a profession of tensions and contradictions, this situation was different because social work's professional identity crisis could not simply be passed over as just 
another point of healthy professional debate. The crisis went beyond the profession's historical quest for status. It is one thing to argue that the professional identity of social workers is 'never stable and is always being negotiated' (Witkin, 1999: 293), yet quite another to threaten the future of a profession trying to heal the wounds of the past (McKendrick, 2001).

The former president of the South African Council for Social Service Professions, Lionel Louw, emphasised that while social workers remained committed to the awesome task of reconstructing South African society and improving the quality of life of its people, their own professional integrity and dignity were being sorely tested due to poor salaries and unsatisfactory work conditions (Louw, 2003). He wondered how social workers as frontline social service practitioners could be expected to effectively meet people's needs when they lacked basic supports like transport and telephones: 'How can a professional service be rendered if practitioners do not have the basic resources with which to do their work?' (Louw, 2003: xv). In addition to poor working conditions, social workers continued to reach out to communities where the risks of falling victim to crime, such as hijacking and theft, were high (van Eeden, 2004).

Social work's struggle for professional identity is a deep and complex issue and the differences that divide the social work profession are just as alive within the government sector, if not more so since, as policy makers, government officials are simultaneously referees and players. They must therefore find common ground in interpreting policies and take the flack for the demoralising impact of their policies on the NGO community. Social workers in both government departments and NGOs have exceptionally high caseloads of 300 to 500 clients and families (Loffell, cited by Du Toit, 2006a: 11). In 2003 the Department of Correctional Services was exposed by a social worker who informed the court that she did not know what to do with an offender sentenced by the judge to correctional supervision. She reported that she managed 800 cases of which 50 still had not been assessed for placement in a community correctional programme (Kemp, 2003). This unfair practice looks worse when measured against the government's caseload norm of 1:60 (Department of Social Development, 2005c: 62).

Although all social workers work under pressure, it is especially intense in NGOs. The situation has been exacerbated by lower salaries in the NGO sector. Even though over the past decade the state has systematically increased the salaries of social workers in the public sector, private NGO sector subsidies have remained static (McKay, 2003). Without additional funding from government, NGOs are unable to compete with government salaries and benefits. Organisations that are serious about transforming their staff complement in accordance with affirmative action policy frequently lose their best social workers to government because of their better salary packages (Koegelenberg, 2003). In a recent survey of children's institutions, child protection and family support organisations by the Gauteng Welfare Crisis Committee (in Du Toit, 2006a), the majority of NGOs reported a staff turnover of nearly 50 per cent over a six-month period. The main reason given was the discrepancy in public and private sector social work salaries. This increasing discrepancy, as well as the fact that NGOs cannot bring their remuneration packages in line with inflation, is paralysing many organisations (Loffell, cited in Du Toit, 2006a).

A 2005 study of 764 NGOs by NACOSS reported an average monthly entry level social work salary of US $\$ 8,440$ compared with US $\$ 11,725$ in government. Supervisors' salaries in NGOs averaged US $\$ 13,108$ as compared with US $\$ 18,134$ for government (National Coalition for Social Services, 2005). Social workers with fulfilling careers in NGOs simply could not make ends meet on this income. Speaking from an NGO perspective, Loffell (cited in Du Toit, 2006a) saw the only solution for stopping this devastating pattern as one where government, with the aid of corporate businesses, adjusted subsidies to NGOs so that salaries could be equalised. Her argument was that without increased salaries for social workers in essential positions, NGOs could not render effective services as NGOs or agents of government (Loffell, cited in Du Toit, 2006a) and more social workers would go overseas or simply leave the profession. Between 1996 and 2003 some 250 social workers left the country to work overseas (Louw, 2003). The exodus of well-trained and committed social 
workers impacted most on the vulnerable (Koegelenberg, 2003). The brain drain from the social work profession prompted the national Ministry for Social Development to call for a national recruitment and retention strategy for social workers. In the second draft of the Recruitment and Retention Strategy for Social Workers in South Africa (Department of Social Development, 2004a), there was an acknowledgement of social work as a scarce skill, a recognition that social workers had appropriate training and skills to deliver effective services and thus, that social workers were key strategic resources. As a first phase in the implementation of the Retention Strategy for Social Workers, the regrading of salaries of social workers in the public service was effected (Department of Social Development, 2005b). The regrading focused not only on salaries, but also on improved and standardised job descriptions and opened up career paths for specialist fields in social work. Although this was a progressive step, once again it benefited state employed social workers which, in turn, only increased their flight from NGOs to government. This severely affected the ability of NGOs to meet their transformation objectives. Personnel appointed in keeping with affirmative action agendas were being trained by NGOs only to be lost to government. Without a full staff complement, NGOs cannot provide effective and consistent services (National Coalition for Social Services, 2005). In February 2006 the Gauteng government announced that NGOs in Gauteng Province would receive subsidies calculated on 75-77 per cent of the entry level government social work salary with an added amount for administration. Although this was a welcome initiative, it still left a long way to go in addressing the backlog in service delivery and in achieving funding parity across the provinces.

Ironically, the negative 'crisis in social welfare' has had positive effects for social workers demoralised by the inconsistencies in and neglect of social services. Over the first ten years of democracy, social workers responded positively to the transformation of welfare through various initiatives that led to the recognition of social work as a scarce skill, including the draft Recruitment and Retention Strategy for Social Workers (Department of Social Development, 2004a), the continuing investigation into the salaries and working conditions of social workers, and the acknowledgement that social services had been neglected at the cost of social security. Finally, the Model of Social Development for Social Service Delivery emerged as an attempt to refocus on developmental social services as mandated in the White Paper for Social Welfare (Republic of South Africa, Ministry for Welfare and Population Development, 1997). Although these achievements have boosted the professional identity and personal esteem of social workers, by themselves they cannot fully restore the morale and confidence of social workers as change agents towards a better society. They merely provide an entry point to assess, from a social work point of view, what is lacking in the transformation of social service delivery from the past residual paradigm to the new, developmental approach. Individual social workers have made huge progress in contributing towards achieving social development goals in South Africa. The acknowledgement of this contribution (see Gray \& Lombard, 2008, this issue) and the provision of hard evidence (Gray, 2000) of social work's impact on social service delivery would prevent further marginalisation of the social work profession.

\section{Conclusion}

Amidst the crisis in social welfare service delivery, the Gauteng Social Service Funding Crisis Committee (2005) asserted that people's quality of life could be improved and poverty eradicated only through the combined resources of government, NGOs, academics, the market, international development agencies, donors and the community (compare Department of Social Development, 2005a). In the first decade of democracy, the relationship between government and NGOs was under extreme pressure. Accumulated differences, misunderstandings and misperceptions exacerbated the tenuous relationship between NGOs and the Department of Social Development (Ramkgopa, cited in Du Toit, 2006b). The Gauteng Social Service Funding Crisis Committee (2005: 5) referred to the 'socalled' partnership between the Department and the NGOs in Gauteng as 'soured'. 
Nevertheless, NGOs remained partners with government, shared its vision and goals for social development (Gauteng Social Service Funding Crisis Committee, 2005: 5), and the tension led to some positive initiatives, such as the draft Recruitment and Retention Strategy for social workers and the Department of Social Development's Integrated Service Delivery Model. The President, Thabo Mbeki, in his State of the Nation Address (Republic of South Africa, 2006a) once again reiterated the government's critical role as one of the country's most important developmental agencies and indicated that government departments should not be allowed to become an obstacle to the achievement of the goal of a better life for all because of ineffective and inefficient service delivery. The crisis in service delivery at the end of the first decade must be addressed in the second decade of democracy. This process has started with the Social Development Summit on the financing and capacity building of non-profit organisations in October 2006, and holds great expectations for shifting the welfare sector into an age of hope in the next ten years of democracy. The non-government sector and civil society more broadly have an essential role to play in making democracy work for the good of all citizens.

\section{References}

- Boyle B (2005). First Lady: State has failed the poor. Sunday Times 11 December: 1.

- De Vries A (2004). Geldknyp kan welsyn erg knou. Organisasies sê staat kap hul hande af, maar minister stry [Money pinch could hit welfare hard. Organisations say government cuts off their hands, but minister argues]. Rapport 11 April.

- Department of Social Development (2004a). Recruitment and Retention Strategy for Social Workers in South Africa. 2nd draft. Pretoria.

- Department of Social Development (2004b). Policy on Financial Awards to Service Providers, 3rd draft. Discussion document. Pretoria.

- Department of Social Development (2005a). Speech by Dr Jean Benjamin, Deputy Minister of Social Development: Launch of the Integrated Service Delivery Model. Media Release. Cape Town International Convention Centre, 28 November.

- Department of Social Development (2005b). Questions for Oral Reply to the Minister of Social Development replied to in the National Council of Provinces (NCOP) on 8 November by Deputy Minister Jean Benjamin on behalf of Minister Zolo Skewyiya.

- Department of Social Development (2005c). The Service Delivery Model for Developmental Social Services. Pretoria.

- Department of Social Development (2005d). Procedure guidelines for the implementation of the Policy on Financial Awards to Service Providers. Pretoria.

- Du Toit P (2006a). Welskynstaat, nie welsynstaat [Welfare pretence state, not welfare state]. Beeld 31 January: 11.

- Du Toit P (2006b). Welsyn-NRO's gaan meer geld kry, beloof LUR. Regering sal werk aan swak verhouding [Welfare-NGOs are going to receive more money, promise MEC. Government will work on poor relationship]. Beeld 15 February: 8.

- Du Toit P (2006c). Welsyn gaan weer vanjaar noustrop trek [Welfare will once again struggle this year]. Beeld 24 February: 4.

- Gauteng Social Services Funding Crisis Committee (2005). Presentation to Social Development Portfolio Committee of the Gauteng Legislature, 27 May.

- Gray M (2000). Social work and the 'social service professions'. Social Work/Maatskaplike Werk 36: 99-109. Links

- Gray M, Lombard A (2008). The post-1994 transformation of social work in South Africa. International Journal of Social Welfare 17(2): 132-145. Links

- Kemp Y (2003). Staff logjam stalls justice, official warns. Staff report. The Cape Argus, Cape Town, 20 May.

- Koegelenberg R (2003). Krisis in welsyn affekteer ryk en arm [Crisis in welfare 
affects rich and poor]. Beeld Forum 2 September.

- Louw LR (2003). Reconstruction challenges to the social service professions.

Editorial, Social Work/Maatskaplike Werk 39: xv-xvi. Links

- McKay P (2003). Welfare in crisis. Social Workers face war of attrition. Children

First 7: 14-15. Links

- McKendrick BW (2001). The promise of social work: Directions for the future.

Social Work/Maatskaplike Werk 37: 105-111. Links

- National Coalition of Social Services (2004). Crisis in the NGO social service delivery system. Memorandum to the Minister for Social Development, Dr ZS Skweyiya, 27 May.

- National Coalition of Social Services (2005). Survey into the salaries of social work practitioners in the non-governmental sector. No website. Email address: mwmrg@iafrica.com

- Republic of South Africa (1994). White Paper on Reconstruction and Development. Notice No. 1954 of 1994. Government Gazette 353 (16085), 23 November.

- Republic of South Africa (1996). The Constitution of the Republic of South Africa. Act 108 of 1996.

- Republic of South Africa (2004). Budget Speech. Minister of Finance, Trevor A. Manuel. Available at http://www.treasury.gov.za [date last accessed 18 February 2004].

- Republic of South Africa (2005). Budget Speech, Minister of Finance, Trevor A. Manuel, 23 February 2005. Available at http://www.treasury.gov.za [date last accessed 13 April 2005].

- Republic of South Africa (2006a). State of the Nation Address of the President of South Africa, Thabo Mbeki. Joint Sitting of Parliament: 3 February 2006. Available at http://www.info.go.za/speeches/index.htm [date last accessed 4 February 2006].

- Republic of South Africa (2006b). Budget Speech, Minister of Finance, Trevor A. Manuel, 15 February 2006. Available at http://www.info.go.za/speeches/index.htm [date last accessed 17 February 2006].

- Republic of South Africa, Department of Welfare (1999). Financing Policy for Developmental Social Welfare Services. Government Gazette, 405 (19888). Pretoria, 26 March. Links

- Republic of South Africa, Ministry for Social Development (2005). Hitting the target in providing social grants. Media Statement, 8 September.

- $\quad$ Republic of South Africa, Ministry for Welfare and Population Development (1997). White Paper for Social Welfare. Notice 1108 of 1997. Government Gazette 386 (18166). Pretoria, 8 August. Links

- Smit A (2005). Funding Strategies: Surviving imperial intentions, protean policies and ruthless reality. Social Work/Maatskaplike Werk 41: 349-360. Links

- Social Development Summit. Financing and Capacity Building of Non-Profit Organisations (2006). Strengthening partnerships to fight poverty and marginalisation. October 2006. Compiled by Themba Msimanga, Department of Social Development and Mike Batley, NPO (Restorative Justice Centre).

- South African Press Association (SAPA) (2003). Government's urgency to make greater use of the private sector in the delivery of social welfare services. Social workers should receive more recognition. Media releases, 18 February and 5 March.

- Statistics South Africa (2005). PO302. Midyear population estimates 2005. Available at http://www.statssa.gov.za [date last accessed 1 March 2005].

- $\quad$ van Eeden J (2004). Totale transformasie. Sederbewakers van ouds word 'n federasie vir almal [Total transformation. Moral guardians of the past become a federation for all]. Rapport 1 August.

- Witkin SL (1999). Identities and contexts. Editorial. Social Work 44: 293-297. Links 